\title{
PENGEMBANGAN MEDIA VIDEO PEMBELAJARAN DENGAN MODEL PENGEMBANGAN 4D PADA MATA PELAJARAN AGAMA HINDU
}

\author{
I Made Tegeh ${ }^{1}$, Alexander Hamonangan Simamora ${ }^{2}$, Kadek Dwipayana ${ }^{3}$ \\ 1,2,3Program Studi Teknologi Pendidikan \\ Universitas Pendidikan Ganesha \\ Singaraja, Indonesia \\ e-mail: im-tegeh@undiksha.ac.id', alexander.simamora@undiksha.ac.id², \\ dwipayana304@gmail.com ${ }^{3}$
}

\begin{abstract}
Abstrak
Seiring perkembangan teknologi yang sangat cepat menyebabkan nilai-nilai agama kurang di perhatikan, sehingga dalam pembelajaran siswa hanya mengetahui namun tidak memahami, padahal ilmu agama merupakan ilmu yang di gunakan sebagai pedoman hidup. Pemahaman siswa terhadap ilmu agama di sebabkan oleh proses pembelajaran yang masih menggunakan metode pembelajaran konvensional tanpa memberikan contoh-contoh konkret dalam proses pembelajaran, sehingga menyebabkan kurangnya pemahaman siswa dan tidak tecapainya hasil belajar secara maksimal. Penelitian ini bertujuan untuk (1) mendeskripsikan rancang bangun video pembelajaran, (2) mendeskripsikan kualitas hasil validitas pengembangan video pembelajaran menurut para ahli dan uji coba produk, (3) mengetahui efektivitas video pembelajaran. Analisis menggunakan analisis deskriptif kualitatif, deskriptif kuantitatif dan analisis statistik inferensial (uji-t). model pengembangan yang di gunakan adalah model 4D, video pembelajaran Agama Hindu valid dengan: (a) hasil review ahli isi mata pelajaran menunjukkan produk berpredikat sangat baik $(93,3 \%)$, (b) hasil review ahli media menunjukkan produk berpredikat sangat baik $(98,6 \%)$, (c) hasil review ahli desain pembelajaran menunjukkan produk berpredikat sangat baik $(93,8 \%)$, (d) hasil uji perorangan menunjukkan produk berpredikat sangat baik $(94,76 \%)$, hasil uji kelompok kecil menunjukkan produk berpredikat sangat baik (95,9\%). Hasil uji lapangan menunjukkan produk berpredikat sangat baik (95,98\%). Efektivitas pengembangan menunjukkan bahwa video pembelajaran Agama Hindu yang dikembangkan efektif meningkatkan hasil belajar Agama Hindu (thitung $=11,368>$ ttabel $=2,042$ pada taraf signifikansi $5 \%$ ). artinya produk terbukti efektif secara signifikan dapat meningkatkan hasil belajar Agama Hindu.
\end{abstract}

Kata-kata kunci : 4D, Agama Hindu, Video Pembelajaran

\begin{abstract}
Along with quick technological development caused religious value less be cared, so that in learning proces, students only knew but did not understand religion besides religion is a science used as life orientation. Students understanding of religion were caused by learning proces that still used convensional learning method without giving concrete examples in learning proces so as caused students lavk of understanding and not achieving maximum students learning outcomes. This research was intended to describe a Hindu learning video, described/explained the result quality of Hindu developing validity learning videos according to experts and product trial, to find out the effectiveness of Hindu learning video. Data analysis used were qualitative descriptive analysis tecnique, deskriptif kuantitatif dan analisis statistik inferensial (uji-t). Developing model used was 4D model, (2) valid Hindu learning video with: review result of subject matter experts showed learning videos of Hindu predicated very well (93.3\%), review result of media expert showed the design predicated very well $(98,6 \%)$, review result of learning design expert showed Hindu learning video predicated very well $(93,8 \%)$, individual test result showed Hindu learning video predicated very well $(94,76 \%)$, small group test result showed Hindu learning video predicated very well (95,9\%). Field test
\end{abstract}


result showed product predicated very well (95,98\%). (3) developing effectiveness showed Hindu learning video which effectively developed increasing result study of Hindu religion ( $\mathrm{t}$ count $=11,368>\mathrm{t}$ table $=2,042$ at the significance level of $5 \%$ ). It means Hindu learning video proven effective in improving the learning outcomes of Hindu effectively.

Keywords: 4D, Learning Video, Hindu

\section{Pendahuluan}

Pendidikan dasar dalam Undang-Undang Sistem Pendidikan Nasional Nomor 20 Tahun 2003 menyebutkan bahwa jenjang pendidikan dimulai dari jenjang pendidikan Sekolah Dasar (SD), jenjang pendidikan Sekolah Menengah Pertama (SMP), jenjang pendidikan Sekolah Menengah Atas (SMA) dan jenjang pendidikan pada Perguruan Tinggi. Pada jenjang pendidikan Sekolah Dasar (SD) merupakan tahap dimana peserta didik memasuki tahap operasional kongkret. Pembelajaran yang di peroleh di Sekolah Dasar ini menjadi awal perkembangan peserta didik untuk melanjutkan ketingkat pendidikan menengah. Pendidikan merupakan salah satu aspek terpenting yang harus dipenuhi oleh manusia dalam kehidupannya. Semakin tinggi jenjang pendidikan yang dilalui maka semakin tinggi juga tingkat intelektual yang dimiliki oleh sesorang. Tingkat intelektual yang tinggi harus diimbangi pula dengan potensi spiritual yang memadai. Untuk meningkatkan potensi spiritual, maka seseorang harus lebih mendekatkan diri kepada Tuhan Yang Maha Esa yaitu melalui sebuah ajaran agama

Berdasarkan Peraturan Menteri Agama Republik Indonesia Nomor 16 Tahun 2010, pendidikan agama adalah "pendidikan yang memberikan pengetahuan dan membentuk sikap, kepribadian dan keterampilan peserta didik dalam mengamalkan ajaran agamanya" Selanjutnya dalam Peraturan Pemerintah Republik Indonesia Nomor 55 Tahun 2007 menyebutkan bahwa pendidikan agama berfungsi membentuk manusia Indonesia yang beriman dan bertakwa kepada Tuhan Yang Maha Esa serta berakhlak mulia. Sedangkan tujuan dari pendidikan agama yaitu untuk mengembangkan kemampuan peserta didik dalam memahami, menghayati, dan mengamalkan nilai-nilai agama yang menyerasikan penguasaannya dalam ilmu pengetahuan dan teknologi.

Berdasarkan keadaan di lapangan, mata pelajaran Agama Hindu merupakan mata pelajaran yang sulit dipahami peserta didik yang beragama Hindu pada umumnya, karena berdasarkan hasil wawancara dengan guru pengampu mata pelajaran Agama Hindu di SD N 2 Suwug bahwa dalam mata pelajaran ini terdapat banyak pemahaman serta mantra-mantra dalam Hindu yang membuat peserta didik harus benar-benar memahami dan menuntut peserta didik untuk lebih banyak menghafal. Apalagi dalam pelajaran agama merupakan suatu materi yang akan di terapkan dalam kehidupan sehari hari, kemudian juga sebagai pembentukan sikap dan ahlak mulia dalam mengamalkan ajaran agama agar lebih mendekatkan diri kepada Ida Sang Hyang Widhi Wasa. Sulitnya memahami pembelajaran Agama ini juga dilihat melalui proses pembelajaran. Pada proses pembelajaran guru atau pendidik biasanya menggunakan metode metode ceramah tanpa memberikan contoh dan melakukan mengajak siswa untuk melakukan praktek.

Pada mata pelajaran Agama Hindu terutama pada materi Penerapan Panca Yadnya Dalam Kehidupan Sehari-hari dalam proses pembelajaran materi pembelajaran disampaiakan dengan cara menggunakan metode ceramah, tanya jawab, dan tugas-tugas. Beberapa permasalahan yang dipaparkan oleh guru bersangkutan, menyebabkan rendahnya kualitas proses pembelajaran mata pelajaran Agama Hindu khususnya kelas $V$ antara lain, (1) Kurang tersedianya sumber bacaan yang relevan dengan materi pelajaran Agama Hindu, (2) Tingkat konsentrasi dan antusias siswa dalam mengikuti pelajaran khusuhnya Agama Hindu, (3) terbatasnya media yang mampu memvisualisasikan materi pelajaran (berbasis teknologi 
informasi dan komunikasi). Dari hasil wawancara dan pengamatan proses pembelajaran di kelas yang menyatakan bahwa nilai rata-rata siswa kelas $\mathrm{V}$ adalah 68 , yang tentunya masih berada dibawah KKM yang ditentukan, yaitu 80 . Bahkan $50 \%$ siswa kelas $\mathrm{V}$ masih ada yang mendapatkan nilai dibawah 70 .

Rendahnya nilai siswa disebabkan proses pembelajaran yang dilaksanakan kurang berkualitas. Sumayana (2015) Salah satu aktor utama dalam mewujudkan kecerdasan manusia adalah guru, sehingga guru menjadi salah satu faktor utama dalam menentukan keberhasilan siswa. Selain itu pemanfaatan media pembelajaran juga sangat dibutuhkan guna meningkatkan kualitas proses pembelajaran. Beberapa ahli memberikan definisi tentang media pembelajaran.Schramm (dalam Arsyad, 2005:3) mengemukakan bahwa media pembelajaran adalah teknologi pembawa pesan yang dapat dimanfaatkan untuk keperluan pembelajaran. Sementara itu, Briggs (dalanm Arsyad, 2005:3) berpendapat bahwa media pembelajaran adalah sarana fisik untuk menyampaikan isi/materi pembelajaran seperti: buku, film, video dan sebagainya.

Dari hasil analisis dan dan wawancara kepada guru pengampu mata pelajaran Agama Hindu kelas V, untuk meningkatkan hasil belajar siswa dibutuhkan inovasi - inovasi dalam pembelajaran khususnya untuk mata pelajaran Agama Hindu. Salah satu inovasi pembelajaran yang bisa digunakan adalah penggunaan media pembelajaran. Media pembelajaran yang cocok digunakan yaitu menggunakan media video pembelajaran dan model pengembangan 4D. Munir (dalam Batu Bara dan Dessy, 2016) mengungkapkan keunggulan media video dalam media pembelajaran antara lain adalah: 1) mampu menjelaskan keadaan nyata suatu proses, fenomena, atau kejadian, 2) mampu memperkaya penjelasan ketika diintegrasikan dengan media lain seperti teks atau gambar, 3) pengguna dapat melakukan pengulangan pada bagian-bagian tertentu untuk melihat gambaran yang lebih fokus, 4) sangat membantu dalam mengajarkan materi dalam ranah perilaku atau psikomor, 5) lebih cepat dan lebih efektif dalam menyampaikan pesan dibandingkan media teks, dan 6) mampu menunjukkan secara jelas simulasi atau prosedural suatu langkah-langkah atau cara (Munir, 2013). Menurut Fahmy dkk (2014) juga menyatakan 1). VBL (Video Bassed Learning) memiliki fitur unik yang menjadikannya pembelajaran yang efektif metode yang dapat meningkatkan dan sebagian menggantikan tradisional pendekatan pembelajaran berbasis kelas dan dipimpin oleh guru. VBL (Video Bassed Learning) dapat mengubah cara kita belajar serta cara kita mengajar. 2).Video dapat membantu siswa dengan memvisualisasikan bagaimana sesuatu bekerja. 3) dan menunjukkan informasi dan detail yang sulit untuk jelaskan dengan teks atau foto statis 4). Selain itu, video bisa menarik perhatian siswa, sehingga memotivasi mereka dan melibatkan mereka untuk meningkatkan kolaborasi mereka. Menggunakan video dengan demikian dapat menyebabkan hasil belajar yang lebih baik 5). Bahkan, video dapat mendukung gaya belajar yang berbeda, khususnyasiswa yang 'pembelajar visual'.

Hal tersebut berarti penggunaan media pembelajaran pada proses pembelajaran khususnya pada mata pelajaran Agama Hindu akan membantu keefektifan proses pembelajaran itu sendiri. Proses pembelajaran yang baik dan berkualitas tentunya harus memenuhi tujuan pembelajaran yang sudah dirancang sebelumnya. Tujuan pembelajaran harus tercapai setiap proses pembelajaran berlangsung, jika tujuan pembelajaran tidak tercapai, maka proses pembelajaran tersebut dapat dikatakan kurang berkualitas. Dengan demikian pemilihan sebuah model pembelajaran merupakan bagian penting dalam merencanakan atau mendesain pembelajaran, agar terjadi interaksi antara siswa dengan guru, siswa dengan siswa maupun siswa dengan sumber belajar lainnya. Salah satu model pembelajaran yang dapat digunakan oleh guru adalah model 4D. Model ini merupakan desain pembelajaran penyajiannya dilakukan secara sederhana, dengan empat tahap yaitu mulai dari Define, Design, Development, dan Disseminate sehingga tidak memakan waktu lama. Saat ini, tingkat pencapaian tujuan pembelajaran di tingkat sekolah dasar disinyalir masih relatif rendah belum mencapai KKM. Dari permasalahan ini antara lain adanya keluhan pendidik (guru) terhadap rendahnya daya serap pembelajaran dalam mengikuti pembelajaran dimana nilai 
akhir siswa terhadap beberapa mata pelajaran khususnya pelajaran Agama Hindu belum memuaskan secara merata. Dari hasil wawancara pada tanggal 7 januari 2019 dengan guru Agama Hindu kelas V di SD Negeri 2 Suwug mengenai hasil belajar.

Berdasarkan paparan di atas dengan menggunakan video pembelajaran di harapkan mampu menambah motivasi siswa dalam belajar. Selain itu SD Negeri 2 Suwug sudah memiliki fasilitas LCD Projector yang menunjang proses belajar mengajar yang digunakan oleh pendidik untuk menyampaikan materi ajar. Sehubungan dengan hal tersebut, maka dalam penelitian ini dicoba untuk melakukan penelitian pengembangan dengan judul "Pengembangan Media Video Pembelajaran Dengan Model Pengembangan 4d Pada Mata Pelajaran Agama Hindu Kelas V di SD Negeri 2 Suwug Tahun Pelajaran 2019/2020".

\section{Metode}

Jenis penelitian ini adalah penelitian pengembangan. Penelitian pengembangan adalah upaya untuk mengembangkan dan menghasilkan suatu produk berupa materi, media, alat dan strategi pembelajaran, yang digunakan untuk mengatasi pembelajaran kelas/laboratorium, dan bukan untuk menguji teori. Dalam pengembangan media video pembelajaran pada mata pelajaran Agama Hindu ini menggunakan model pengembangan 4D. Pemilihan model pembelajaran ini didasari atas pertimbangan bahwa desain pembelajaran model 4D ini penyajian model di lakukan secara sederhana. Dalam pengembangan media video pembelajaran ini terdiri dari 4 fase atau tahap utama, yaitu Define, desain, development and Disseminate.

Tahap uji coba produk dalam penelitian pengembangan ini terdiri atas : a) rancangan uji coba produk, dan b) subyek coba produk Pada penelitian pengembangan video pembelajaran berbasis pendekatan kontekstualini menggunakan empat metode dalam pengumpulan data, yaitu wawancara, pencatatan dokumen, kuesioner, dan tes.

Pada instrumen soal-soal tes tipe pilihan ganda sebelum digunakan ke lapangan maka diteliti dulu kualitasnya, dengan memenuhi kualitas isinya, maka terhadap instrument soal-soal tes tipe pilihan ganda ini dilakukan expert judgement oleh orang yang ahli di bidangnya, setelah itu dilakukan uji coba instrumen untuk mengetahui kesahihan (validitas) dan keterandalannya (reliabilitas) dari instrument tersebut, karena kualitas intrumen harus memenuhi persyaratan penting yaitu: (1) validitas butir tes, (2) reliabilitas tes, (3) daya pembeda tes, dan (4) tingkat kesukaran butir tes.

Pengujian hipotesis digunakan uji-t berkorelasi dan pentashihan hasil dengan penghitungan manual. Sebelum melakukan uji hipotesis (uji-t berkorelasi) dilakukan uji prasyarat (normalitas dan homogenitas).

\section{Hasil dan Pembahasan}

Penelitian ini dilaksanakan pada kelas $\mathrm{V}$ semester genap di SD N 2 Suwug Tahun Pelajaran 2018/2019 dari tanggal 24 April sampai 30 Mei 2018. Subjek dalam penelitian ini adalah seluruh siswa kelas $\mathrm{V}$ yang berjumlah 16 orang. Adapun pengembangan Video Pembelajaran ini dilakukan dengan menggunakan model 4D, yaitu: (1) Tahap Define (Pendefinisian) (2) Tahap Design (Perancangan), (3) Tahap Development (Pengembangan), dan (4) Tahap Disseminate (Penyebarluasan).

Penyajian data uji coba menjelaskan tentang hasil validitas pengembangan produk berupa Video Pembelajaran Agama Hindu. Dimana hasil validitas pengembangan Video ini akan dipaparkan enam hal pokok, meliputi: validitas pengembangan Video menurut (1) ahli isi mata pelajaran, (2) ahli desain pembelajaran, (3) ahli media pembelajaran, (4) uji coba perorangan, (5) uji coba kelompok kecil, dan (6) uji coba lapangan. 
Sesuai dengan model pengembangan produk yang digunakan dalam pengembangan Video Pembelajaran ini yaitu model pengembangan 4D, ada 4 tahapan yang dilalui. Adapun tahapan-tahapan dalam pelaksanaan penelitian yaitu:

\section{Tahap Define}

Di dalam tahap ini, Pada tahap ini dilakukan untuk menetapkan dan mendefinisikan syarat-syarat pengembangan. syarat yang dimaksud ialah sebuah hal yang mampu memperlihatkan kebutuhan mendasar mengapa diperlukannya mengembangkan sebuah media video pembelajaran di SD N 2 Suwug. Untuk itu, diperlukan 3 analisis yang berbeda untuk dapat mancari pokok permasalahan yang ada. Tiga jenis analisis yang dimaksud, yaitu: (1) analisis kebutuhan, (2) analisis lingkungan/ fasilitas, (3) analisis mata pelajaran.

Untuk menganalisis kebutuhan peserta didik di buat instrumen untuk mengetahui kebutuhan dari peserta didik. Di dalam tahap ini, peneliti mencari permasalahan yang ada di SD N 2 Suwug untuk mendapatkan informasi mengenai gaya belajar peserta didik, tingkat kemampuan peserta didik dan masalah-masalah apa yang dihadapi guru di dalam kelas.

Berdasarkan hasil pencatatan dokumen ditemukan rata-rata nilai terendah siswa kelas $\mathrm{V}$ terletak pada mata pelajaran Agama Hindu. Berdasarkan hasil wawancara dengan guru Agama Hindu ditemukan masalah, kurangnya minat belajar siswa pada mata pelajaran agama hindu. Berdasarkan pengalaman Guru agama hindu kelas V di SD N 2 Suwug menyatakan bahwa siswa kurang berkonsentrasi saat mengingkuti pelajaran, sehingga nilai yang didapatkan siswa masih belum dapat dimaksimalkan atau tergolong paling rendah dibandingkan nilai-nilai pada mata pelajaran lain.

Berdasarkan hasil kuesioner diketahui bahwa siswa Kelas V, SD 2 Suwug menyatakan belajar Agama Hindu sulit, lebih mudah memahami materi pelajaran dan lebih senang menggunakan media pembelajaran audio visual daripada media cetak.

\section{Tahap II Perancangan (Design)}

Perancangan Video menurut Herliyani (2014) beberapa konsep yang dirancang, yaitu a) Konsep Desain, b) Konsep Media, c) Konsep Naskah.

Target audience ditujukan untuk rentang umur diatas 10 tahun. Video pembelajaran ini bertujuan untuk pendidikan. Apabila ditujukan untuk siswa, guru dapat menayangkan Video pembelajaran ini di depan kelas, serta orang tua juga dapat berperan mendampingi anak dirumah dengan memfasilitasi anak dengan alat pemutar video, seperti Smartphone, Laptop, dll untuk menayangkan Video Pembelajaran ini. Apabila ditujukan untuk bukan siswa, harus memiliki alat pemutar video.

Konsep media dilakukan untuk menyimpan hasil jadi video, yaitu CD yang diberi label disertai tempat/kotak CD yang diberi cover sesuai dengan materi yang dijelaskan pada video.

Shooting script merupakan naskah video/film yang berisi uraian lengkap setiap adegan (shot), babak (scene), jenis musik, efek suara (sound effects) hubungan antara gambar dan suara, sudut pengambilan kamera, jenis shot, lokasi/ruang, sumber visual dan pemain sehingga akan mempermudah pelaksanaan dalam proses produksi. Hasil dari penulisan shooting script digunakan sebagai pedoman atau arahan dalam proses pembuatan film/video agar hasilnya lebih terstruktur.

\section{Tahap III Pengembangan (Development)}

Terdapat 3 tahap pada tahap pengembangan yaitu (1) tahap produksi dan (2) tahap implementasi (3) Evaluasi. Pada tahap Produksi dari Video pembelajaran terdapat Naskah yang dikembangkan menjadi produk yang sesungguhnya, pada tahap ini menghasilkan produk Video pembelajaran. Pada Tahap produksi Kegiatan yang pertama dilakukan adalah pengumpulan bahan atau materi bahan ajar, adapun bahan tersebut didapatkan dari buku Agama Hindu kelas $\mathrm{V}$ dan sumber lainnya yang relevan dengan materi yang diangkat pada Video pembelajaran. Kemudian syuting video, Pengambilan Video di lakukan di pura Segara desa Bungkulan menggunakan dua buah kamera DSLR dan beberapa perangkat pendukung 
lain seperti tripod dan mic. Setelah semua scene selesai kemudian akan digabungkan menggunakan aplikasi Adobe Premiere Pro CC 2019.

Setelah Video selesai, tahap selanjutnya lanjutkan dengan implementasi produk. Pada tahap implementasi dimaksudkan untuk menerapkan efektivitas produk yang telah dibuat dilapangan. Dalam implementasi produk, hal-hal yang dilakukan yaitu dilakukan uji coba produk meliputi: ahli isi mata pelajaran, uji ahli media pembelajaran, ahli desain pembelajaran, , uji coba perorangan, uji coba kelompok kecil dan uji coba lapangan. Untuk uji perorangan dilakukan oleh 3 orang siswa kelas $\mathrm{V}$ dengan hasil belajar tinggi, sedang dan rendah, sedangkan untuk uji coba kelompok kecil dilakukan oleh siswa kelas $\mathrm{V}$ dengan jumlah responden sebanyak 9 orang siswa dengan hasil belajar tinggi, sedang, dan rendah.

Pada tahap ini Video Pembelajaran Agama Hindu yang dikembangkan kemudian dilakukan uji coba lapangan pada siswa kelas V di SD N 2 Suwug. Sebelum Video pembelajaran diimplementasikan pada siswa, terlebih dahulu siswa diberikan pre-test untuk mengukur pengetahuan awal siswa terhadap materi yang ada pada video pembelajaran. Tes yang digunakan sebagai pre-test sudah melalui tahap uji coba ahli dan uji validitas butir tes di kelas V di SD N 4 Suwug. Jumlah soal pre-test berjumlah 20 butir soal. Setelah mengerjakan soal pre-test kemudian dilanjutkan dengan implementasi Video pembelajaran Agama Hindu.

Implementasi Video pembelajaran Agama hindu dilakukan 1 kali pertemuan dengan alokasi waktu 90 menit. Pada saat implementasi guru menggunakan laptop, sound system, Proyektor yang telah difasilitasi sekolah sebagai media untuk memutar Video pembelajaran di dalam kelas.

Pada tahap akhir penilaian dilakukan untuk memvalidasi produk yang telah dibuat melalui uji ahli produk. Uji validasi produk bertujuan untuk menguji tingkat keajegan produk yang sudah dibuat, sedangkan uji efektivitas bertujuan untuk mengukur tingkat efektivitas produk yang dibuat. Pada setiap tahap pengembangan video pembelajaran terdapat evaluasi dan revisi yang dilakukan demi perbaikan produk yang dihasilkan. Penilaian yang dilakukan yaitu penilaian formatif, yaitu penilaian yang dilakukan sepanjang proses pengembangan media, serta penilaian sumatif yaitu penilaian yang dilakukan untuk mengetahui efektif atau tidaknya produk yang dikembangkan dalam proses pembelajaran dengan melakukan uji efektivitas.

Hasil analisis data terhadap pengembangan video pembelajaran akan dipaparkan dua hal yang berkaitan dengan hasil evaluasi produk, meliputi: (1) Analisis hasil validitas pengembangan video pembelajaran, (2) Analisis efektivitas pengembangan Video pembelajaran. Adapun kedua hasil analisis data tersebut akan dipaparkan lebih lanjut, sebagai berikut.

Hasil validitas pengembangan Video pembelajaran menurut uji ahli isi mata pelajaran, uji ahli desain pembelajaran, uji ahli media pembelajaran, uji coba perorangan, uji coba kelompok kecil dan uji coba lapangan secara lebih rinci dapat disajikan pada Tabel 2.

Tabel 2. Persentase Hasil Validitas Pengembangan Video Pembelajaran

\begin{tabular}{clcc}
\hline No & Subjek Uji Coba Video Pembelajaran & Hasil Validitas (\%) & Keterangan \\
\hline 1. & Uji Ahli Isi Mata Pelajaran & 93,3 & Sangat Baik \\
2. & Uji Ahli Desain Pembelajaran & 93,8 & Sangat Baik \\
3. & Uji Ahli Media Pembelajaran & 98,6 & Sangat Baik \\
4. & Uji Coba Perorangan & 94,7 & Sangat Baik \\
5. & Uji Coba Kelompok Kecil & 95,9 & Sangat Baik \\
6. & Uji Coba Lapangan & 95,9 & Sangat Baik \\
\hline
\end{tabular}

Hasil validitas pengembangan video pembelajaran secara keseluruhan memperoleh persentase sangat baik. 
Efektivitas pengembangan video pembelajaran dilakukan dengan metode tes pilihan ganda. Soal tes pilihan ganda digunakan untuk mengumpulkan data nilai hasil belajar siswa sebelum dan sesudah menggunakan Video pembelajaran. Tujuan mengumpulkan data nilai siswa, agar dapat mengetahui tingkat efektivitas penggunaan Video pembelajaran terhadap peningkatan hasil belajar yang dilakukan dengan cara menggunakan uji t untuk sampel berkorelasi.

Berdasarkan hasil perhitungan menggunakan uji $t$ diperoleh hasil $t$ hitung sebesar 11,368. $t$ hitung tersebut selanjutnya dibandingkan dengan $t$ tabel pada taraf signifikansi $5 \%$ dengan $\mathrm{db}=\mathrm{n}_{1}+\mathrm{n}_{2}-2=16+16-2=32-2=30$ adalah sebesar 2,042. Hasil tersebut menunjukkan bahwa thitung $>t_{\text {tabel}}$, sehingga $\mathrm{H}_{0}$ ditolak dan $\mathrm{H}_{1}$ diterima. Ini berarti terdapat perbedaan yang signifikan (5\%) sebelum menggunakan Video Pembelajaran Pembelajaran Agama Hindu pada kelas V di SD N 2 Suwug Tahun Pelajaran 2018/2019 dan sesudah menggunakan Video Pembelajaran Agama Hindu pada kelas V SD N 2 Suwug Tahun Pelajaran 2018/2019

Video Pembelajaran Agama hindu yang dihasilkan dalam penelitian ini adalah media yang ditujukan untuk siswa dapat belajar dengan baik untuk perkembangan kognitifnya dan memotivasi siswa, kemudian dapat mempermudah guru dalam kegiatan pembelajaran dan mengelola kelas.

Hasil penelitian ini menunjukkan bahwa Video Pembelajaran Agama Hindu yang dikembangkan telah melalui serangkaian tahap pengembangan dan telah divalidasi oleh para ahli dibidangnya serta telah diuji cobakan. Dalam pengembangannya, Video Pembelajaran Agama Hindu ini sudah melewati beberapa tahap uji coba dan perbaikan. Berikut ini pembahasan dari hasil pengembangan Video Pembelajaran Agama Hindu berdasarkan proses pengembangan Video pembelajaran, validitas/kelayakan Video pembelajaran, dan efektivitas video pembelajaran. Semua tahap ini dilakukan untuk menyempurnakan Video Pembelajaran Agama Hindu sehingga benar-benar mampu dan layak digunakan dalam pembelajaran.

\section{Simpulan dan Saran}

Berdasarkan hasil dan pembahasan yang telah dipaparkan dapat disimpulkan bahwa (1) mengembangkan video pembelajaran Agama Hindu dengan model pengembangan 4D meliputi empat tahapan, yaitu (a)Define, (b) Design, (c) Development, (d) Dessminate. (2) Video pembelajaran Agama Hindu valid dengan: (a) Hasil review ahli isi mata pelajaran menunjukkan video pembelajaran agama hindu berpredikat sangat baik $(93,3 \%)$, (b) Hasil review ahli desain pembelajaran menunjukkan video pembelajaran agama hindu berpredikat sangat baik $(93,8 \%)$, (c) Hasil review ahli media pembelajaran menunjukkan video pembelajaran agama hindu berpredikat sangat baik $(98,6 \%)$, (d) Hasil uji coba perorangan video pembelajaran agama hindu berpredikat sangat baik $(94,76 \%)$, hasil uji coba kelompok kecil video pembelajaran agama hindu berpredikat sangat baik $(95,9 \%)$, dan hasil uji coba lapangan video pembelajaran agama hindu berpredikat sangat baik (95,98\%). (3) Efektivitas pengembangan Video pembelajaran agama hindu yang dikembangan efektif meningkatkan hasil belajar agama hindu ( $t_{\text {hitung }}=11,368>t_{\text {tabel }}=2,042$ pada taraf signifikansi $5 \%$. Ini berarti bahwa video pembelajaran agama hindu terbukti secara signifikan dapat meningkatkan hasil belajar Agama hindu.

Berdasarkan hasil penelitian, pembahasan dan simpulan dapat diajukan beberapa saran sebagai berikut. (1) Bagi siswa, disarankan agar dapat memanfaatkan Video pembelajaran secara optimal. Video pembelajaran tidak hanya dimanfaatkan di sekolah saja, namun dapat dimanfaatkan di mana dan kapan saja pada saat siswa ingin belajar. Dengan pemanfaatan Video pembelajaran agama hindu secara maksimal, maka diharapkan hasil belajar siswa akan meningkat lebih optimal. (2) Bagi guru mata pelajaran khususnya mata pelajaran Agama, hasil penelitian ini dapat digunakan sebagai salah satu alternatif model pembelajaran untuk menciptakan pemahaman yang lebih cepat terhadap proses pembelajaran dan menggunakan Video pembelajaran sebagai salah satu media pembelajaran yang dapat 
membangkitkan minat belajar siswa dan pembelajaran menjadi lebih efektif lagi. (3) Bagi sekolah, disarankan agar guru-guru dapat mengembangkan kreativitas dan lebih mengaktifkan siswa dalam proses belajar mengajar melalui modelmodel pembelajaran yang inovatif. Selain itu pihak sekolah juga harus menambah sarana dan prasarana penunjang proses pembelajaran agar proses pembelajaran nantinya lebih efektif dan mampu menambah daya tarik siswa dalam memahami materi pembelajaran. (4) Bagi peneliti lain, dapat bermanfaat untuk memperoleh pengalaman langsung dan hasil penelitian ini dapat menjadi informasi bagi para peneliti bidang pendidikan untuk meneliti aspek atau variabel lain yang diduga memiliki kontribusi terhadap konsep-konsep dan teori-teori dalam pembelajaran dan juga sebagai refrensi untuk dapat melakukan kegiatan serupa dengan ruang lingkup yang lebih luas.

\section{Daftar Pustaka}

Arsyad, Azhar. 2011. Media Pembelajaran. Jakarta: PT Rajagrafindo Persada.

Dimyati dan Mudjiono. 2006. Belajar dan Pembelajaran. Jakarta: PT Rineka Cipta. Mahadewi, Luh Putu Putrini. 2014. Problematika Teknologi Pendidikan. Yogyakarta: Graha IImu

Firmandhika, Armandha. 2012. "Pengembangan Media Video Pembelajaran Pada Mata Pelajaran Agama Hindu Materi Ukuran Bidang Pandang Pengambilan Gambar Untuk Siswa Kelas VI Multimedia SMKN 2 Buduran Sidoarjo". https://ejournal.undiksha.ac.id/index.php/KP/article/view/6725/4563, Vol. 1, No. 1 (diakses pada tanggal 18 oktober 2018).

Prawiradilga, Dewi Salma. 2007. Prinsip Desain Pembelajaran. Jakarta: Prenadamedia Group.

Putri, Novitasari. 2015. "Pengembangan E-Modul Mata Pelajaran Multi Media (Paket Keahlian Multimedia) Dengan Model Pembelajaran Task Based Learning Pada Kelas V Di SMK 3 Mataram". https://ejournal.undiksha.ac.id/index.php/KP/article/view/6620/4508, Vol. 4, No. 5 (diakses pada tanggal 18 oktober 2018).

Batubara dan Dessy. 2016 "Pemanfaatan Video sebagai Media Pembelajaran Matematika SD/MI" https://media.neliti.com/media/publications/222485-pemanfaatan-video-sebagaimedia-pembelaj.pdf" Vol.2, No. 1 (diakses pada tanggal 10 November 2018).

Purwati, Budi. 2015 "Pengembangan Media Video Pembelajaran Matematika dengan Model Assure"http://ejournal.umm.ac.id/index.php/jmkpp/article/download/2194/2344Vol. 3, No.15(diakses pada tanggal 10 November 2018).

Sadiman, Arief S, dkk. 2009. Media pendidikan: pengertian, pengembangan dan pemanfaatannya. Jakarta: PT. Raja Grafindo Persada.

Fahmy, Ahmed M, dkk. 2014. "The State of Video-Based Learning: A Review and Future Perspectives" https://pdfs.semanticscholar.org/adbb/a2031b01cf1dea52cf1dfe181446f151f9ed.pdf Vol. 6, No 3 (diakses pada tanggal 10 Desember 2018).

Sudarma, I Komang, dkk. 2015. Desain Pesan: Kajian Analisis Desain Visual Teks dan Image. Yogyakarta:Graha IImu.

Undang-Undang Republik Indonesia Nomor 20 Tahun 2003 tentang Sistem Pendidikan Nasional Peraturan Pemerintah Republik Indonesia Nomor 55 Tahun 2007 tentang fungsi agama 
Setiawan, I Nyoman Rai. 2017 "Struktur, Nilai Pendidikan Karakter Hindu Dan Tanggapan Anak Nyastra Tentang Santi Parwa" https://media.neliti.com/media/publications/266336struktur-nilai-pendidikan-karakter-hindu-c78ba1aa.pdfVol. 16, No.01 (diakses pada tanggal 12 Januari 2019).

Wuryanti, Umi dan Badrun Kartowagiran. 2016 "Pengembangan Media Video Video Untuk Meningkatkan Motivasi Belajar Dan Karakter Kerja Keras Siswa Sekolah Dasar" https://media.neliti.com/media/publications/123228-ID-pengembangan-media-videovideo-untuk-m.pdfVol. 6, No.2 (diakses pada tanggal 12 Januari 2019).

Fadhli, Muhibuddin. 2015 "Pengembangan Media Pembelajaran Berbasis Video Kelas V Sekolah Dasar". https://www.researchgate.net/publication/313860243_Pengembangan_Media_Pembelaj aran_Berbasis_Video_Kelas_Iv_Sekolah_DasarVol. 3, No.1 (diakses pada tanggal 12 Januari 2019).

Qonita Silmi, Munida dan Putri Rachmadyanti. 2018 "Pengembangan Media Pembelajaran Video Video Berbasis Sparkol Videoscribe Tentang Persiapan Kemerdekaan Ri Sd Kelas V" https://media.neliti.com/media/publications/254987-pengembangan-mediapembelajaran-video-an-3ce95323.pdf Vol. 03, No.04 (diakses pada tanggal 12 Januari 2019).

Fauzan Aziz, dan Dwi Rahdiyanta. 2017 “ Pengembangan Media Pembelajaran Berbasis Video Pada Teori Pemesinan Frais". https://journal.uny.ac.id/index.php/dynamika/article/download/15994/9761 Vol. 2, No. 2 (diakses pada tanggal 25 Maret 2019).

Aditya, Arya. 2017 " Penggunaan Media Pembelajaran Audio Visual Untuk Meningkatkan Hasil Belajar IPS Pada Siswa Kelas IV SD" http://ejournal.upi.edu/index.php/mimbar/article/download/5227/pdf Vol. 4, No. 1 (diakses pada tanggal 25 Maret 2019

Dewi, Risna. 2016 "Pengembangan Video Pembelajaran Berbasis Kearifan Lokal Mata Pelajaran Bahasa Bali Untuk Siswa Kelas III". https://ejournal.undiksha.ac.id/index.php/JEU/article/download/7630/5202 Vol. 5, No. 2 (di akses pada tanggal 3 Mei 2019) 